\title{
PENGARUH REALISASI PENERIMAAN PAJAK DAERAH DAN RETRIBUSI DAERAH TERHADAP REALISASI PENDAPATAN ASLI DAERAH (PAD) KOTA CILEGON TAHUN 2014-2018
}

\author{
Sev Rahmiyanti ${ }^{1}$, Didit Prasetyo ${ }^{2}$ \\ Universitas Banten Jaya ${ }^{1}$ \\ Kantor Pelayanan Kekayaan Negara dan Lelang (KPKNL) Serang ${ }^{2}$ \\ Serang, Indonesia \\ $\underline{\text { sevrahmiyanti@unbaja.ac.id }^{1}, \text { diditacong@gmail.com }^{2}}$
}

\begin{abstract}
ABSTRAK
This research was conducted to determine the effect of local taxes and levies on local revenue. This study uses data on the realization of the Regional Expenditure Budget and is devoted to the data on the realization of the revenue of the original region of Cilegon which was taken over a period offive years, starting from 2014 un til 2018 . The data was obtained from the Badan Pengelolaan Keuangan dan Aset Kota Cilegon with the type of data used is time series data.The results of this study indicate the effect of local tax revenue and regional retribution in the city of Cilegon have a positive effect simultaneously on the increase of local revenue with a magnitude of influence of $94.8 \%$, while partially local tax and regional levies have different influences in influencing local revenue. It can be concluded that regional taxes have a significant effect on local own-source revenues while regional user fees do not have a significant effect on regional own-source revenues.
\end{abstract}

Keywords: regional taxes, levies and local own-source revenues.

\section{PENDAHULUAN}

Penyelenggaraan otonomi daerah secara penuh adalah cita - cita semua daerah di Indonesia. Salah satu sumber keuangan yang diperoleh untuk kelanjutan cita - cita tersebut adalah bersumber dari Pendapatan Asli Daerah (PAD) yang berasal dari berbagai komponen seperti pajak daerah, retribusi daerah, laba BUMD dan pendapatan lain yang sah. Hal ini menunjukan bahwa PAD dapat dijadikan salah satu sumber keuangan yang dapat diandalkan dalam proses penyelenggaraan pemerintah di daerah. Setiap penyelenggaraan pemerintah daerah harus benar - benar menggali secara maksimal apa-apa yang menjadi sumber potensi sebagai sumber pendapatan tersebut. Sehingga, dalam pelaksanaan otonomi daerah tidak mengalami ketertinggalan 


\section{PROGRESS}

Jurnal Pendid ikan, Akuntansi dan Keuangan

Universitas Banten Jaya
Vol 3 No. 1, Februari 2020

E-ISSN 2622-7037 |P-ISSN 2623-0763 dalam semua aspek terutama yang berhubungan dengan pembiayaan.

Tujuannya utama dikeluarkannya kebijakan otonomi daerah antara lain adalah membebaskan pemerintah pusat dari beban beban yang tidak perlu dalam menangani urusan daerah. Dengan demikian pusat berkesempatan mempelajari, memahami, merespon berbagai kecenderungan global dan mengambil manfaat dari padanya. Pada saat yang sama pemerintah pusat diharapkan lebih mampu berkonsentrasi pada perumusan kebijakan makro (luas atau yang bersifat umum dan mendasar) nasional yang bersifat strategis.

Di lain pihak, dengan desentralisasi daerah akan mengalami proses pemberdayaan yang optimal. Kemampuan prakarsa dan kreativitas pemerintah daerah akan terpacu, sehingga kemampuannya dalam mengatasi berbagai masalah yang terjadi di daerah akan semakin kuat.

Sebagai administrator penuh, masingmasing daerah harus bertindak efektif dan efisien agar pengelolaan daerahnya lebih terfokus dan mencapai sasaran yang telah ditentukan.Pelaksanaan tugas tersebut tidak semudah membalikkan telapak tangan karena salah satunya perlu kemampuan ekonomi yaitu; pertama adalah tentang bagaimana pemerintah daerah dapat menghasilkan finansial untuk menjalankan organisasi termasuk memberdayakan masyarakat, kedua bagaimana pemerintah daerah melihat fungsinya mengembangkan kemampuan ekonomi daerah (Nugroho I, Dahuri, R 2004).

Mengacu pada UU No. 23 Tahun 2014 Tentang Pemerintahan Daerah yang merupakan revisi dari UU No. 32 Tahun 2004 tentang Pemerintahan Daerah menyatakan bahwa Otonomi Daerah adalah hak, wewenang, dan kewajiban daerah otonom untuk mengatur dan mengurus sendiri Urusan Pemerintahan dan kepentingan masyarakat setempat dalam sistem Negara Kesatuan Republik Indonesia. Selanjutnya yang dimaksud dengan Daerah Otonomyang selanjutnya disebut Daerah adalah kesatuan masyarakat hukum yang mempunyai batas-batas wilayah yang berwenang mengatur dan mengurus urusan pemerintahan dan kepentingan masyarakat setempat menurut prakarsa sendiri berdasarkan aspirasi masyarakat dalam sistem Negara Kesatuan Republik Indonesia.

Otonomi daerah dipacu untuk dapat berkreasi mencari sumber penerimaan daerah yang dapat mendukung pembiayaan pengeluaran daerah. Dari berbagai alternatif 
sumber penerimaan yang mungkin dipungut oleh daerah, Undang-undang tentang penerimaan daerah menetapkan pajak dan retribusi daerah menjadi sumber penerimaan yang berasal dari dalam daerah dan dapat dikembangkan sesuai kondisi masingmasing daerah.

Untuk merealisasikan keinginan dalam menetapkan otonomi guna mengurangi ketergantungan daerah pada pemerintah pusat. Maka Pemerintah Pusat telah menetapkan undang-undang Nomor 33 Tahun 2004 tentang perimbangan keuangan antara pemerintah pusat dan daerah. Hal ini mengisyaratkan diberlakukannya otonomi daerah, dimana pemerintah daerah baik pemerintah provinsi, pemerintah kabupaten, maupun kota telah diberikan wewenang untuk mengatur rumah tangga daerah sendiri melalui otonomi daerah yang mengedepankan kemandirian daerah.

Pelaksanaan otonomi daerah yang dititikberatkan pada Daerah Kabupaten dan Daerah Kota dimulai dengan adanya penyerahan sejumlah kewenangan (urusan) dari pemerintah pusat ke pemerintah daerah yang bersangkutan. Penyerahan berbagai kewenangan dalam rangka desentralisasi ini tentunya harus disertai dengan penyerahan dan pengalihan pembiayaan.
Sumber pembiayaan yang paling penting adalah sumber pembiayaan yang dikenal dengan istilah pendapatan asli daerah di mana komponen utamanya adalah penerimaan yang berasal dari komponen pajak daerah dan retribusi daerah.

Pertumbuhan komponen pajak daerah dan retribusi daerah akan menjadi faktor yang penting dalam mendorong pertumbuhan pendapatan asli daerah serta mendorong peningkatan kemampuan peranan perusahaan daerah untuk dapat memberikan kontribusinya kepada pendapatan asli daerah.

Kota Cilegon dikenal sebagai kota industri. Sebutan lain bagi Kota Cilegon adalah Kota Baja mengingat kota ini merupakan penghasil baja terbesar di Asia Tenggara. Sekitar 6 juta ton baja dihasilkan tiap tahunnya di Kawasan Industri Krakatau Steel, Cilegon. Di Kota Cilegon terdapat berbagai macam objek vital negara, antara lain Pelabuhan Merak, Pelabuhan Cigading Habeam Centre, Kawasan Industri Krakatau Steel, PLTU Suralaya, PLTU Krakatau Daya Listrik, Krakatau Tirta Industri Water Treatment Plant, (Rencana Lot) Pembangunan Jembatan Selat Sunda dan (Rencana Lot) Kawasan Industri Berikat Selat Sunda. Dengan banyaknya kegiatan 
industri skala besar yang terdapat di Cilegon makaterdapat potensi untuk menghasilkan pajak daerah dan retribusi daerah yang bersumber dalam kawasan Kota Cilegon.

"Pajak adalah prestasi kepada pemerintah yang terutang melalui normanorma umum, dan yang dapat dipaksakan, tanpa ada kalanya kontraprestasi yang dapat ditunjukan dalam hal yang individual; maksudnya adalah untuk membiayai pengeluaran pemerintah."

Menurut undang-undang Nomor 28 Tahun 2007, pajak adalah kontribusi wajib kepada negara yang terutang oleh orang pribadi atau badan yang sifatnya memaksa berdasarkan undang-undang dengan tidak mendapat timbal balik secara langsung dan digunakan untuk keperluan negara untuk sebesar-besarnya kemakmuran rakyat.

Sesuai dengan UU Nomor 28 Tahun 2009 tentang PDRD, pajak daerah adalah kontribusi wajib kepada daerah yang terutang oleh orang pribadi atau badan yang bersifat memaksa berdasarkan undangundang, dengan tidak mendapatkan imbalan secara langsung dan digunakan untuk keperluan Daerah bagi sebesar-besarnya kemakmuran rakyat.
Pajak daraha adalah yang dipungut oleh pemerintah daerah dan digunakan untuk membiayai rumah tangga daerah.

Pajak daerah terdiri dari :

(1) Pajak Propinsi, contoh; pajak kendaraan bermotor dan kendaraan di atas air, pajak bahan bakar kendaraan bermotor.

(2) Pajak kabupaten/kota, contoh; pajak hotel, pajak restoran, pajak hiburan, pajak reklame, dan pajak penerangan jalan.

Pengertian Retribusi daerah dikemukakan oleh Mardiasmo. (2002 : 100), menyatakan bahwa yang dimaksud Retribusi daerahadalah "Retribusi daerah, yang selanjutnya disebut Retribusi adalah pemungutan daerah sebagai pembayaran atas jasa atau pemberian izin tertentu yang khusus disediakan dan/atau diberikan oleh Pemerintah Daerah untuk kepentingan pribadi atau badan". Retribusi yang dipungut oleh pemerintah Indonesia sekarang diatur dalam Undang-undang Nomor 18 Tahun 1997 sebagaimana yang telah diubah dengan Undang-undang Nomor 34 Tahun 2000 tentang pajak daerah dan retribusi daerah. Dalam Undang-undang ini yang dimaksud dengan retribusi adalah pungutan sebagai pembayaran atas jasa yang disediakan oleh 
Pemerintah Daerah dengan objek sebagai berikut:

1) Jasa umum, yaitu jasa untuk kepentingan dan pemanfaatan umum serta dapat dinikmati oleh orang pribadi atau badan;

2) Jasa usaha, yaitu jasa yang menganut prinsip komersial karena pada dasarnya dapat pula disediakan oleh sektor swasta;

3) Perizinan tertentu, yaitu kegiatan pemda dalam rangka pembinaan, pengaturan, pengendalian, dan pengawasan atas kegiatan, pemanfaatan ruang, penggunaan sumber daya alam, barang, prasarana, sarana atau fasilitas tertentu guna melindungi kepentingan dan menjaga kelestarian lingkungan.

Retribusi daerah adalah pungutan daerah sebagai pembayaran atas jasa atau pemberian izin tertentu yang khusus disediakan dan/atau diberi oleh pemerintah daerah untuk kepentingan orang pribadi atau badan.

Retribusi Daerah merupakan bagian dari Pendapatan Asli Daerah (PAD) yang diharapkan menjadi salah satu sumber pembiayaan penyelenggaraan pemerintah dan meratakan kesejahteraan masyarakat. Daerah Kabupaten/Kota diberi kewenangan dalam menggali potensi sumber-sumber keuntungannya dengan menetapkan jenis retribusi selain yang telah ditetapkan, sepanjang memenuhi kriteria yang telah ditetapkan dan sesuai dengan aspirasi rakyat.

Definisi Pendapatan Daerah menurut Peraturan Menteri Dalam Negeri Nomor 13 Tahun 2006 adalah hak pemerintah daerah yang diakui sebagai penambah nilai kekayaan bersih. Adapun jenis Pendapatan sebagaimana tertuang dalam Pasal 25 dikelompokkan atas:

1) Pendapatan Asli Daerah;

2) Dana Perimbangan; dan

3) Lain-lain Pendapatan Daerah yang Sah.

Pendapatan Asli Daerah adalah penerimaan yang diperoleh daerah dari sumber-sumber dalam wilayahnya sendiri yang dipungut berdasarkan peraturan daerah yang sesuai dengan peraturan perundang-undangan yang berlaku. 


\section{Gambar 1. Kerangka Pemikiran}

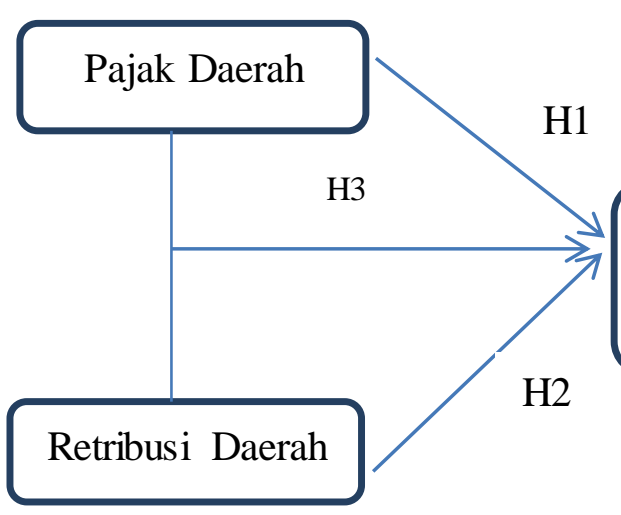

H1: Pengaruhpajak daerah terhadap pendapatan asli daerah (PAD) Kota Cilegon

$\mathrm{H} 2$ : Pengaruhretribusi daerah terhadap pendapatan asli daerah (PAD) Kota Cilegon

H3: Pengaruhpajak daerah dan retribusi daerah terhadap pendapatan asli daerah (PAD) Kota Cilegon

\section{METODE PENELITIAN}

Pendekatan yang digunakan dalam penelitian ini adalah pendekatan kuantitatif. Penelitian kuantitatifmenurut Sugiyono (2012;7) merupakan metode penelitian yang berlandaskan pada filsafat positivisme, digunakan untuk meneliti pada populasi atau sampel tertentu. Teknik pengambilan sampel pada umumnya dilakukan secara random, pengumpulan data menggunakan instrumen
Pendapatan Asli Daerah

(PAD) Kota Cilegon (Y)

penelitian, analisis bersifat kuantitatif atau statistik dengan tujuan untuk menguji hipotesis yang telah ditetapkan.

Metode yang digunakan dalam pengumpulan data penelitian ini adalah metode dokumentasi. Menurut Sugiyono (2014), Dokumen merupakan catatan peristiwa yang sudah berlalu. Dokumen bisa berbentuk tulisan, gambar, atau karya-karya monumental dari seseorang, bisa berbentuk catatan harian, foto, gambar, dan sejarah kehidupan. Dalam penelitian ini, dokumentasi dilakukan dengan mengumpulkan sumber-sumber data dokumenter seperti laporan tahunan (annual report) pada situs resmi Badan Pengelolaan Keuangan dan Aset Daerah Kota Cilegon (http://bpkad.cilegon.go.id/).

Analisis data menurut Sunyoto $(2013 ; 24)$ analisis data terdiri dari: 
1. Analisis kualitatif

Analisis kualitatif merupakan analisis non statistik yang membantu dalam penelitian yang kemudian ditafsirkan dengan baik.

2. Analisis kuantitatif

Analisis kuantitatif adalah analisis yang menggunakan rumus-rumus statistik untuk perhitungan angka-angka dalam rangka menganalisis data yang diperoleh.

Untuk menjelaskan pengaruh penerimaan pajak daerah dan retribusi daerah terhadap pendapatan Asli Daerah Kota Cilegon, maka penulis menggunakan analisis kuantitatif. Analisis kuantitatif dilakukan dengan analisis deskriptif, uji normalitas, uji hipotesis.

Teknik analisis dalam penelitian ini adalah sebagai berikut:

1. Analisis Deskriptif.

Penelitian ini merupakan penelitian deskriptif dengan populasi dan sampel Kota Cilegon. Data dalam penelitian ini bersumber laporan APBD Pemerintahan Kota Cilegon yakni data PAD, Pajak Daerah, Retribusi Daerah dan penerimaan lain-lain yang diperoleh dari kantor Badan Pengelolaan Keuangan dan Aset Daerah Kota Cilegon. Analisis deskriptif digunakan untuk memberikan gambaran secara umum mengenai data sehingga dapat dilihat nilai maksimum, minimum, rata-rata, serta standar deviasinya.

2. Uji Normalitas

Uji normalitas bertujuan untuk menguji apakah dalam model regresi, variasi pengganggu atau residual memiliki distribusi normal, jika terdapat normalitas, maka residual akan terdetribusi secara normal dan independent, yaitu perbedaan antara nilai prediksi dengan skor yang sesungguhnya atau error akan terdestribusi secara simetri disekitar nilai means sama dengan nol.

Untuk uji normalitas data, penulis menggunakan uji Kolmogorov-Smirnov dengan taraf signifikansi $0,05 \quad(5 \%)$. Apabila signifikasinya lebih dari 0,05 maka dapat disimpulkan bahwa data terdestribusi secara normal.

\section{HASIL PENELITIAN DAN \\ PEMBAHASAN}

\section{Hasil Penelitian}

\section{Uji Statistik Deskriptif}

Statistik deskriptif keseluruhan variabel penelitian yang mencakup nilai minimum, 
maksimum, rata-rata, dan standar deviasi dibawah ini: adalah seperti yang terlihat pada pada tabel

Tabel 1. Hasil Analisis Deskriptif

\begin{tabular}{lrrrrr}
\hline & \multicolumn{5}{c}{ Descriptive Statistics } \\
& N & Minimum & Maximum & \multicolumn{1}{c}{ Mean } & \multicolumn{1}{c}{$\begin{array}{c}\text { Std. } \\
\text { Deviation }\end{array}$} \\
\hline Pajak Daerah & 5 & 340,32 & 455,91 & 406,1240 & 43,50006 \\
Hasil Retribusi Daerah & 5 & 14,37 & 25,88 & 18,9630 & 4,51528 \\
Pendapatan Asli & 5 & 467,95 & 652,08 & 569,1220 & 65,79187 \\
Daerah & 5 & & & & \\
Valid N (Listwise) & 5 & & & & \\
Sumber: Output SPSS & & & &
\end{tabular}

Tabel 1 dapat dijelaskan bahwa jumlah data (N) yang di uji sebanyak 5. Selain itu diperoleh gambaran nilai minimum, maksimum, nilai rata-rata, serta standar deviasi masing-masing variabel adalah sebagai berikut:

a. Pajak Daerah sebagai variabel $\mathrm{X}_{1}$

Penerimaan Pajak Daerah dalam kurun waktu 5 tahun terkhir ini yaitu pada tahun 2014 sampai 2018 yang menunjukan penerimaan terbesar terdapat pada tahun 2017 sebesar Rp 455,91 miliar, sedangkan penerimaan terkecil terdapat pada tahun 2014 sebesar Rp. 340,32 miliar. Rata-rata penerimaan pajak daerah adalah sebesar Rp. 406,1240 miliar dengan standar deviasi Rp. 43,50006 miliar. b. Retribusi Daerah sebagai variabel $\mathrm{X}_{2}$ Penerimaan Hasil Retribusi Daerah waktu 5 tahun terkhir ini yaitu pada tahun 2014 sampai 2018, yang menunjukan penerimaan terbesar terdapat pada Tahun 2016 sebesar Rp. 25,88 miliar, sedangkan penerimaan terkecil terdapat pada tahun 2014 sebesar Rp. 14,37miliar. Rata-rata penerimaan hasil retribusi daerah adalah sebesar Rp. 18,9630 miliyar dengan standar deviasi Rp. 4,51528 miliar.

c. Pendapatan Asli Daerah

Selama kurun 5 tahun terakhir ini yaitu pada tahun 2014 sampai tahun 2018 dapat diketahui bahwa jumlah PAD terbesar terdapat pada Tahun 2017 sebesar Rp 652,08 miliar, sedangkan penerimaan terkecil terdapat pada Tahun 2014 sebesar Rp. 467,95 miliar. Rata-rata penerimaan PAD 
PROGRESS

Jurnal Pendidikan, Akuntansi dan Keuangan Universitas Banten Jaya adalah sebesar Rp. 569,1220 miliar, dengan standar deviasi Rp. 65,79187 miliar

\section{Pengujian Hipotesis}

Pengujian hipotesis dalam penelitian ini yang dapat dirumuskan sebagai berikut:

1) Hipotesis $1 \quad(\mathrm{H} 1)$ : $\quad$ Terdapat pengaruhpajak daerah terhadap pendapatan asli daerah (PAD) Kota Cilegon

2) Hipotesis 2 (H2): Terdapat pengaruhretribusi daerah terhadap pendapatan asli daerah (PAD) Kota Cilegon

3) Hipotesis $3 \quad$ (H3): $\quad$ Terdapat pengaruhpajak daerah dan retribusi daerah terhadap pendapatan asli daerah (PAD) Kota Cilegon

Pengujian didasarkan dengan dasar pengambilan keputusan sebagai berikut:
1) Uji t

a) Jika nilai sig $<0,05$, atau $t$ hitung $>\mathrm{t}$ tabel maka terdapat pengaruh parsial variabel $\mathrm{X}$ terhadap variabel $\mathrm{Y}$

b) Jika nilai sig $>0,05$, atau $t$ hitung $<\mathrm{t}$ tabel maka tidak terdapat pengaruh parsial variabel $\mathrm{X}$ terhadap variabel $\mathrm{Y}$

2) Uji $F$

a) Jika nilai sig $<0,05$, atau $\mathrm{F}$ hitung $>\mathrm{F}$ tabel maka terdapat pengaruh variabel $\mathrm{X}$ secara simultan terhadap variabel $\mathrm{Y}$

b) Jika nilai sig $>0,05$, atau $F$ hitung $<F$ tabel maka tidak terdapat pengaruh variabel $\mathrm{X}$ secara simultan terhadap variabel $\mathrm{Y}$

\section{Uji Normalitas}

Uji Normalitas yang digunakan dalam penelitian ini adalah dengan uji Statistik dengan kolomogorov-smirnov seperti terlihat pada tabel berikut:

Tabel 2. Hasil Uji Normalitas

One-Sample Kolmogorov-Smirnov Test

Unstandardized

\begin{tabular}{llr} 
& & Residual \\
\hline $\mathrm{N}$ & & 5 \\
Normal Parameters $^{\mathrm{a}, \mathrm{b}}$ & Mean &, 0000000 \\
& Std. & 14,93918135 \\
& Deviation &, 281 \\
Most Extreme & Absolute &, 151 \\
Differences & Positive &,- 281 \\
& Negative &, 281 \\
Test Statistic & &, $200^{\mathrm{c}, \mathrm{d}}$ \\
Asymp. Sig. (2-tailed) & & \\
\hline
\end{tabular}




$\frac{\overline{\text { a. Test distribution is Normal. }}}{\text { Sumber: Output SPSS }}$

Tabel 2 dapat diketahui bahwa nilai signifikansiyang dihasilkan dari uji normalitas dengan one sample kolomogorov-smirnovtest terhadapa variable pajak daerah (X1), Retribusi Daerah (X2) dan Pendapatan Asli Daerah (Y) adalah $0,200>0,05$ atau dapat dijabarkan bahwa signifikansi 0,200yang mana lebih besar dari $0,05(5 \%)$. Maka dapat disimpulkan bahwa nilai residual mempunyai distribusi normal karena nilai signifikansinya diatas 0,05 sehingga data tersebut layak dilanjutkan dengan uji asumsi klasik.

\section{Uji Regresi Berganda}

Hasil uji regresi berganda yang
digunakan untuk mengetahui ada atau
tidaknya pengaruh antar variabel adalah
sebagai berikut:

\section{Tabel 3 Variabel Terkait Pada Regresi Berganda Variables Entered/Removed ${ }^{\text {abh }}$}

\begin{tabular}{llll}
\hline Model & \multicolumn{1}{c}{$\begin{array}{l}\text { Variables } \\
\text { Entered }\end{array}$} & $\begin{array}{c}\text { Variables } \\
\text { Removed }\end{array}$ & Method \\
\hline 1 & $\begin{array}{l}\text { Retribusi } \\
\text { Daerah, } \\
\end{array}$ & & \\
& Pajak Daerah & \\
& & & . Enter \\
& &
\end{tabular}
a. Dependent Variable: PAD
b. All requested variables entered.

Sumber: Output SPSS

Tabel 3 menunjukan variabel $\mathrm{X}_{1}$ atau Pajak Daerah dan $X_{2}$ atau Retribusi Daerah yang menjadi variabel bebas, sedangkan variabel $\mathrm{Y}$ atau Pendapatan Asli Daerah adalah variabel terikat.

Tabel 4. Hasil Korelasi Regresi Berganda

\section{Model Summary}

Adjusted R

\begin{tabular}{|c|c|c|c|c|}
\hline Model & $\mathrm{R}$ & R Square & Square & Std. Error of the Estimate \\
\hline 1 &, $974^{\mathrm{a}}$ & ,948 & ,897 & 21,12719 \\
\hline
\end{tabular}

Sumber: Output SPSS 


\section{PROGRESS}

Jurnal Pendidikan, Akuntansi dan Keuangan Universitas Banten Jaya
Vol 3 No. 1, Februari 2020

E-ISSN 2622-7037 |P-ISSN 2623-0763
Tabel 4 menunjukan Model Summary diperoleh nilai koefesien determinasi $R$ Square $=0,948$ yang berarti sekitar 94,8 \% variabel Pajak Daerah dan Retribusi Daerah dapat menjelaskan variabel Pendapatan Asli Daerah Kota Cilegon. Nilai ini merupakan nilai yang tinggi dan mencerminkan terjadinya hubungan kuat antara variabel bebas $\mathrm{X}_{1}$ dan $\mathrm{X}_{2}$ dan variabel terikat $\mathrm{Y}$, dan nilai Adjusted $\mathrm{R}$ Square juga menunjukan nilai yang tinggi yaitu 0,948 .

Tabel 5. Perolehan Nilai Koefesien Regresi Berganda

\begin{tabular}{|c|c|c|c|c|c|}
\hline \multirow[b]{3}{*}{ Model } & \multicolumn{3}{|c|}{ Coefficients $^{\text {a }}$} & \multirow[b]{3}{*}{$\mathrm{t}$} & \multirow[b]{3}{*}{ Sig. } \\
\hline & \multicolumn{2}{|c|}{$\begin{array}{l}\text { Unstandardized } \\
\text { Coefficients }\end{array}$} & \multirow{2}{*}{$\begin{array}{c}\text { Standardized } \\
\text { Coefficients } \\
\text { Beta }\end{array}$} & & \\
\hline & B & Std. Error & & & \\
\hline $\begin{array}{ll}1 & \text { (Constant) }\end{array}$ & $-50,225$ & 106,355 & &,- 472 & ,683 \\
\hline $\begin{array}{l}\text { Pajak } \\
\text { daerah }\end{array}$ & 1,456 & ,243 & ,963 & 5,985 & 027 \\
\hline $\begin{array}{l}\text { Retribusi } \\
\text { daerah }\end{array}$ & 1,478 & 2,344 & , 101 & 631 &, 593 \\
\hline
\end{tabular}

a. Dependent Variable: PAD

\section{Sumber: Output SPSS}

Tabel 5 menujukan nilai

koefesien/parameter regresi linear berganda diatas $\mathrm{a}=-50,225, \mathrm{~b} 1=1,456$ dan $\mathrm{b} 2=$ 1,478. Sehingga persamaan regresi yang diperoleh adalah : $\mathrm{Y}=-50,225+1,456 \mathrm{X}_{1}+$

\section{Uji $\mathbf{t}$}

Hasil uji $t$ yang digunakan untuk mengetahui ada atau tidaknya pengaruh parsial antar variabel dalam penelitian ini dapat dilihat pada tabel berikut: $1,478 \mathrm{X}_{2}$

Tabel 6. Hasil Uji t

\section{Coefficients ${ }^{2}$}

\section{Unstandardized Standardized

Coefficients Coefficients

\begin{tabular}{|c|c|c|c|c|c|}
\hline \multirow{2}{*}{$\frac{\text { Model }}{1 \quad \text { (Constant) }}$} & B & Std. Error & Beta & $\mathrm{t}$ & Sig. \\
\hline & $-50,225$ & 106,355 & &,-- 472 &, 683 \\
\hline $\begin{array}{l}\text { Pajak } \\
\text { daerah }\end{array}$ & 1,456 & 243 & 963 & 5,985 & ,027 \\
\hline $\begin{array}{l}\text { Retribusi } \\
\text { daerah }\end{array}$ & 1,478 & 2,344 & 101 & 631 & ,593 \\
\hline
\end{tabular}

a. Dependent Variable: PAD

Sumber: Output SPSS 
Tabel 6 dilakukan untuk menyelidiki lebih lanjut, mana diantara variabel independent yang berpengaruh terhadap Pendapatan Asli Daerah (PAD). Uji t dilakukan dengan membandingkan $\mathrm{t}$ hitung dengan $\mathrm{t}$ tabel, taraf signifikansi 5\%:2=2,5\% (uji 2 sisi) dengan derajat kebebasan (df) = n-k-1 atau 5-2-1=2 (n adalah jumlah sampel dan $\mathrm{k}$ adalah jumlah variabel independent). Dengan pengujian 2 sisi (Signifikan = 0,025), maka hasil yang diperoleh untuk $\mathrm{t}$ tabel sebesar 4,303. Sehingga didapat hasil pengujian sebagai berikut:

(1) Variabel pajak daerah memiliki $t$ hitung sebesar 5,985 dengan taraf signifikansi 0,027 dibawah signifikansi $0,05(5 \%)$. Dengan demikian t hitung > $\mathrm{t}$ tabel atau 5,985>4,303.

(2) Variabel retribusi daerah memiliki $t$ hitung 0,631 dengan taraf signifikansi 0,593 diatas signifikansi $0,05 \quad(5 \%)$. Dengan demikian $\mathrm{t}$ hitung $<\mathrm{t}$ tabel atau $0,693<4,303$.

Dari hasil perolehan uji $\mathrm{t}$ seperti pada tabel 6 dengan membandingkan $\mathrm{t}$ hitung dengan $\mathrm{t}$ tabel pada kedua variabel bebas, yaitu nilai uji $\mathrm{t}$ pada variabel pajak daerah $(5,985>4,303)$ dan retribusi daerah $(0,693<4,303)$ maka dapat disimpulkan bahwa kedua variabel secara parsial memiliki pengaruh yang berbeda dalam mempengaruhi Pendapatan Asli Daerah (PAD). Dapat disimpulkan bahwa Pajak Daerah mempunyai pengaruh yang signifikan terhadap pendapatan asli daerah yang berarti hipotesis 1 (H1) dapat diterima sedangkan Retribusi Daerah tidak mempunyai pengaruh yang signifikan terhadap Pendapatan Asli Daerah yang berarti hipotesis $2(\mathrm{H} 2)$ tidak dapat diterima.

\section{Hasil uji F (fisher)}

Hasil uji F yang digunakan untuk mengetahui ada atau tidaknya pengaruh simultan antar variabel dalam penelitian ini dapat dilihat pada tabel berikut: 
Tabel 7. Hasil Uji F ANOVA $^{\mathrm{a}}$

\begin{tabular}{llrrrrr}
\hline & \multicolumn{1}{c}{ Sum of } & & & & \\
Model & Squares & Df & Mean Square & F & \multicolumn{1}{c}{ Sig. } \\
\hline $1 \quad$ Regression & 16421,566 & 2 & 8210,783 & 18,395 &, $052^{\mathrm{b}}$ \\
& Residual & 892,717 & 2 & 446,358 & & \\
$\quad$ Total & 17314,282 & 4 & & &
\end{tabular}

a. Dependent Variable: PAD

b. Predictors: (Constant), Retribusi daerah, Pajak daerah Sumber: Output SPSS

Uji F dilakukan untuk menyelidiki lebih lanjut, apakah variabel independent secara simultan berpengaruh terhadap Pendapatan Asli Daerah (PAD) sebagai variabel dependent. Uji $F$ dilakukan dengan membandingkan $\mathrm{F}$ hitung dengan $\mathrm{F}$ tabel, taraf signifikansi $5 \%(0,05)$ dengan rumus $\mathrm{F}$ tabel $=\mathrm{F}(\mathrm{k}, \mathrm{n}-\mathrm{k})$ atau $\mathrm{F}=(2,3) \quad(\mathrm{n}$ adalah jumlah sampel dan $\mathrm{k}$ adalah jumlah variabel independent). Dari pengujian tersebut maka hasil yang diperoleh untuk $\mathrm{F}$ tabel adalah sebesar 9,55. Dari tabel 7 menunjukan hasil uji $F$ sebesar 18,395 dengan tingkat signifikansi 0,052 yang mana diatas signifikansi $0,05(5 \%)$ dan $\mathrm{F}$ hitung $>\mathrm{F}$ tabel atau $18,395>9,55$.

Dari uji diatas didapat kesimpulan bahwa secara signifikasi $0,052>0,05$ namun secara perbandingan antara $F$ hitung dan $\mathrm{F}$ tabel didapat $\mathrm{F}$ hitung $>\mathrm{F}$ tabel atau 18,395 > 9,55. Karena sudah memenuhi dasar pengambilan keputusan dalam uji $\mathrm{F}$ yang mana disyaratkan jika $F$ hitung $>F$ tabel maka terdapat pengaruh variabel $\mathrm{X}$ secara simultan terhadap variabel $\mathrm{Y}$ maka dapat dikatakan bahwa hipotesis yang telah dikemukakan pada landasan teori, kedua variabel independent yaitu variabel Pajak Daerah dan Retribusi Daerah secara bersama-sama atau simultan mempengaruhi variabel dependent yaitu Pendapatan Asli Daerah. Maka hipotesis 3 (H3) yang dikemukakan dapat diterima.

\section{Koefisien Determinasi}

Hasil uji koefisien determinasiyang berfungsi untuk mengetahui berapa persen pengaruh variabel bebas $(\mathrm{X})$ secara simultan terhadap variabel terikat (Y) dalam penelitian ini dapat dilihat pada tabel pada tabel dibawah ini: 
Tabel 8. Hasil Analisis Determinasi

\begin{tabular}{|c|c|c|c|c|}
\hline \multicolumn{5}{|c|}{ Model Summary } \\
\hline & & & Adjusted $\mathrm{R}$ & \\
\hline Model & $\mathrm{R}$ & R Square & Square & Std. Error of the Estimate \\
\hline$\overline{1}$ &, $974^{\mathrm{a}}$ & ,948 & 8 & 21 \\
\hline
\end{tabular}

a. Predictors: (Constant), Retribusi daerah, Pajak daerah

\section{Sumber: Output SPSS}

Tabel 8 dapat diketahui bahwa hasil Adjusted R Square adalah 0,948 atau 94,8\%. Hal ini menunjukan bahwa Pendapatan Asli Daerah dapat dijelaskan oleh variabel pajak daerah dan retribusi daerah sebesar 94,8\%, sedangkan sisanya $5,2 \% \quad(100 \%-94,8 \%)$ dijelaskan oleh faktor-faktor lain diluar penelitian, seperti hasil pengelolaan kekayaan daerah yang dipisahkan dan lainlainpendapatan asli daerah yang disahkan.

Hasil dari pengujian hipotesis yang telah dijabarkan pada subbab sebelumnya. Dari hasil pengujian hipotesis dapat diikhtisarkan sebagai berikut:

1. Berdasarkan uji t,variabel pajak daerah mempunyai $\mathrm{t}$ hitung sebesar 5,985 dengan taraf signifikansi 0,027 dibawah signifikansi 0,05 (5\%). Dengan demikian $\mathrm{t}$ hitung $>\mathrm{t}$ tabel atau 5,985> 4,303 sehingga disimpulkan bahwa Pajak Daerah mempunyai pengaruh yang signifikan secara parsial terhadap pendapatan asli daerah yang berarti hipotesis 1 (H1) dapat diterima yang berarti semakin besar jumlah pajak daerah yang diterima maka akan semakin besar pula penerimaan pendapatan asli daerah Kota Cilegon. Hasil tersebut konsisten dengan penelitian Regina Usman (2016) yang menunjukkan bahwa pajak daerah berpengaruh signifikan terhadap pendapatan asli daerah.

2. Berdasar uji t, variabel retribusi daerah memiliki $\mathrm{t}$ hitung 0,631 dengan taraf signifikansi 0,593 diatas signifikansi 0,05 (5\%). Dengan demikian t hitung $<\mathrm{t}$ tabel atau $0,693<4,303$ sehinggaretribusi daerah tidak mempunyai pengaruh yang signifikan secara parsial terhadap Pendapatan Asli Daerah yang berarti hipotesis 2 (H2) tidak dapat diterimasehingga besar kecilnya penerimaan retribusi daerah belum tentu berpengaruh terhadap penerimaan pendapatan asli daerah Kota Cilegon. Hasil penelitian ini konsisten dengan penelitian Regina Usman (2016) dan Lakoy (2016) bahwa tidak ada 
pengaruh yang signifikan dari retribusi daerah terhadap pendapatan asli daerah.

3. Berdasar uji $\mathrm{F}$, perbandingan antara $\mathrm{F}$ hitung dan $\mathrm{F}$ tabel didapat $\mathrm{F}$ hitung $>\mathrm{F}$ tabel atau 18,395>9,55 sehingga variabel pajak daerah dan retribusi daerah secara bersama-sama atau simultan mempengaruhi variabel dependent yaitu Pendapatan Asli Daerah yang berarti hipotesis 3 (H3) yang dikemukakan dapat diterimadan dapat disimpulkan pajak daerah dan retribusi daerah berpengaruh signifikan terhadap pendapatan asli daerah. Hasil tersebut konsisten dengan penelitian Regina Usman (2016) yang menunjukkan bahwa penerimaan pajak daerah dan retribusi daerah berpengaruh signifikan terhadap pendapatan asli daerah.

Dari model regresi didapatkan persamaan regresi sebagai berikut:

$$
Y=-50,225+1,456 X 1+1,478 X 2
$$

\section{Dimana :}

Y = Pendapatan Asli Daerah

$\mathrm{X} 1=$ Pajak Daerah

$\mathrm{X} 2=$ Retribusi Daerah

Persamaan diatas dapat disimpulkan sebagai berikut :

1. Nilai konstansta yang diporoleh adalah 50,225 menyatakan bahwa jika variabel independen pajak daerah dan retribusi daerah bernilai nol, diasumsikan bahwa jumlah pendapatan asli daerah yang diperoleh sebesar $-50,225$.

2. Koefisien regresi pajak daerah bernilai positif 1,456 menyatakan bahwa setiap kenaikan satu satuan pajak daerah maka diperkirakan pendapatan asli daerah akan meningkat sebesar 1,456 dengan asumsi bahwa variabel lain bernilai tetap.

3. Koefisien regresi retribusi daerah bernilai positif 1,478 menyatakan bahwa setiap kenaikan satu satuan retribusi daerah maka diperkirakan pendapatan asli daerah akan meningkat sebesar 1,478 dengan asumsi variabel lain bernilai tetap. 
Tabel 9. Fluktuasi Komponen PAD Kota Cilegon Tahun 2014-2018

\begin{tabular}{lcccccc}
\hline Tahun & $\begin{array}{c}\text { Pajak } \\
\text { Daerah } \\
\text { (Milyar) }\end{array}$ & Fluktuasi & $\begin{array}{c}\text { Retribusi } \\
\text { Daerah } \\
\text { (Milyar) }\end{array}$ & Fluktuasi & $\begin{array}{c}\text { Asli } \\
\text { Daerah } \\
\text { (Milyar) }\end{array}$ & Fluktuasi \\
\hline 2014 & 340,32 & - & 14,37 & - & 467,95 & - \\
2015 & 412,61 & $21 \%$ & 20,125 & $40 \%$ & 579,58 & $24 \%$ \\
2016 & 392,55 & $-5 \%$ & 25,88 & $29 \%$ & 567,66 & $-2 \%$ \\
2017 & 455,91 & $16 \%$ & 15,61 & $-40 \%$ & 652,08 & $15 \%$ \\
2018 & 429,23 & $-6 \%$ & 18,83 & $21 \%$ & 578,34 & $-11 \%$ \\
\hline
\end{tabular}

Dari hasil penelitian diketahui bahwa angka realisasi penerimaan pajak daerah dan retibusi daerah Kota Cilegon mempunyai kecenderungan untuk berfluktuasi dan tidak stabil. Pertumbuhan realisasi penerimaan atas pajak daerah dan retribusi daerah yang bergerak naik turun tersebut juga berpengaruh pada realisasi atas Pendapatan Asli Daerah Kota Cilegon. Hal terserbut dapat terlihat dalam tabel 8 dimana terjadi kenaikan pada tahun 2015 sebesar 24\% dan tahun 2017 sebesar 15\% namun mengalami penurunan pada tahun 2016 sebesar $-2 \%$ dan tahun 2018 sebesar -11\%. Kecenderungan berfluktuasi atas komponen Pendapatan Asli Daerah Kota Cilegon ini disinyalir disebabkan oleh faktor dimana banyak sumber-sumber pajak daerah dan retribusi daerah yang belum digali dan kurangnya kemampuan pemerintah daerah dalam menggali sumber-sumber penerimaan yang ada.

Bila diamati lebih jauh terdapat persamaan dalam pola fluktuasi antara pajak daerah dan pandapatan asli daerah. Kesamaan pola terlihat dimana mengalami kenaikan pada tahunyang sama yaitu tahun 2015 dan 2018 serta mengalami pola penurunan juga pada tahun yang sama yaitu pada tahun 2016 dan tahun 2018. Hal yang berbeda ditemukan pada pola fluktuasi retribusi daerah yang mempunyai tren kenaikan selama tahun 2015, 2016 dan 2018 yaitu sebesar 40\%, 29\%, dan $21 \%$. Penurunan retribusi daerah dalam periode tahun 2014 sampai dengan 2018 hanya terjadi pada tahun 2017 yaitu sebesar $-40 \%$. Jika melihat data tersebut dimana terdapat kesamaan pola fluktuasi antara pajak daerah dan pendapatan asli daerah serta data bahwa 
retribusi daerah mempunyai pola fluktuasi yang berbeda dari komponen lainnya semakin menguatkan hasil penelitian ini yang mengungkapkan bahwa terdapat pengaruh yang signifikan pajak daerah terhadap pendapatan asli daerah dan juga hasil penelitian yang mengungkapkan bahwa tidak terdapat pengaruh yang signifikan atas retribusi daerah terhadap pendapatan asli daerah.

\section{KESIMPULAN}

Penelitian ini bertujuan untuk mengetahui pengaruh pajak daerah dan retribusi daerah terhadap pendapatan asli daerah (PAD) Kota Cilegon. Data-data yang menyangkut penelitian ini diperoleh dari Kantor Badan Pengelolaan Keuangan dan Aset Daerah Kota Cilegon. Sampel data yang diambil dalam penelitian ini data perolehan pendapatan asli daerah selama 5 Tahun(2014-2018).

Berdasarkan hasil pengujian yang telah dilakukan maka dapat ditarik kesimpulan sebagi berikut:

1. Pajak Daerah memiliki pengaruh yang signifikan terhadap Pendapatan Asli Daerah (PAD) ini dibuktikan pada hasil nilai t hitung 5,985> nilai $\mathrm{t}$ tabel 4,303.
2. Hasil Retribusi Daerah tidak memiliki pengaruh yang signifikan terhadap Pendapatan Asli Daerah (PAD) ini dibuktikan pada hasil t hitung 0,693 < nilai $\mathrm{t}$ tabel 4,303 .

3. Pajak Daerah dan Retribusi Daerah secara bersama-sama berpengaruh terhadap Pendapatan Asli Daerah (PAD) ini dibuktikan pada hasil uji $\mathrm{F}$ karena nilai $\mathrm{F}$ hitung18,395 > F tabel 9,55 .

\section{DAFTAR PUSTAKA}

Danang Sunyoto, (2011), Parktik SPSS untuk Kasus, dilengkapi Contoh Penelitian Bidang Ekonomi, Nuha Medika, Yogyakarta

Hasan, Iqbal. (2013), Analisis Data Penelitian Dengan Statistik. Bumi Aksara. Jakarta.

Indonesia tax Review. "Mengintip Amandemen UU Pajak". Volume VII/ Edisi 05. 2007

Mardiasmo. (2002 : 100$)$. Perpajakan. Yogyakarta, Andi.

Mardiasmo. (2011), perpajakan, Edisi Revisi. Yogyakarta. Andi.

Margono. (2010). Metodolgi Penelitian. Jakarta: Rineka cipta.

Nugroho I, Dahuri, R(2004). Pembangunan Wilayah : Perspektif Ekonomi, Sosial dan Linkungan, Jakarta : LP3ES. 
Moleong, L.J. (2011). Metode Penelitian Kualitatif Edisi Revisi. Bandung. PT Remaja Rosdakarya.

Regina Usman (2016), Jurnal. "Pengaruh Pajak Daerah dan Retribusi Daerah Terhadap Pendapatan Asli Daerah (PAD) (Studi Kasus pada Pemerintah Daerah Kota Bandung periode 2011-2015)".

Suandy, Erly. (2011), Perpajakan, Edisi Revisi. Salemba Empat.

Sugiyono. (2014). Metode Penelitian Kuantitatif, Kualitatif, dan $R \& D$. Cetakan ke-17. Bandung. Alfabeta.

Siahaan. Marihot.P. (2010). Pajak Daerah Dan Retribusi Daerah. Edisi revisicet. 2. Jakarta. PT Grafindo Persada.

Sukmadinata, Nana Syaodih. (2011). Metode Penelitian .Bandung: PT Remaja Rosdakarya.

Mahmudi, 2007, Analisis Laporan Keuangan Pemerintah Daerah. Yogyakarta: UPP STIM YKPN.

Mardiasmo. 2006. Perpajakan Edisi Revisi. Yogyakarta: ANDI.

Marsyahrul, Tony. 2006. Pengantar Perpajakan. Jakarta: PT.Grasindo.

Sekaran, Uma. 2010. Metodologi Penelitian untuk Bisnis. Jakarta: Salemba Empat.

Siahaan. 2006. Pajak Daerah dan Retribusi Daerah. Jakarta: PT.Raja Grafindo Persada.
BadanPusatStatistik.2019.Kota Cilegon Dalam Angka.Kota Cilegon:Badan PusatStatistik Kota Cilegon

Kumpulan Peraturan Daerah Kota Cilegon Tentang Pajak Daerah Dan Retribusi Daerah. 2019.

Peraturan Menteri Dalam Negeri No. 2 Tahun 2006 Tentang Perhitungan Dasar Pengenaan Pajak Kendaraan Bermotor dan Bea Balik Nama Kendaraan Bermotor Tahun 2006. Jakarta: Kementerian Dalam Negeri

Keputusan Menteri Dalam Negeri Nomor 25 Tahun 2010 tentang Penghitungan

Dasar PKB dan BBNKB. 2010. Jakarta: Departemen Dalam Negeri.

Undang-Undang Nomor 32 Tahun 2004 Tentang Pemerintahan Daerah. 2004.

Jakarta: Kementerian Dalam Negeri.

Undang-Undang Nomor 33 Tahun 2004 tentang Perimbangan Keuangan Antara

Pusat dan Daerah 2000. Jakarta: Kementerian Keuangan

Undang-Undang Nomor 34 tahun 2000 Tentang Pajak Daerah dan Retribusi

Daerah. 2000. Jakarta: Kementerian Keuangan.

Undang-Undang Republik Indonesia Nomor 28 Tahun 2009 Tentang Pajak

Daerah dan Retribusi Daerah. 2009. Jakarta: Direktorat Jenderal Pajak. 